\title{
Биографическая статья
}

DOІ: $10.22363 / 2313-1683-2019-16-2-287-292$

УДК 159.99

\section{Мой научный руководитель - ГМ: к 95-летию со дня рождения Г.М. Андреевой}

\author{
И.Б. Бовина \\ Московский государственный психолого-педагогический университет \\ Российская Федерация, 127051, Москва, ул. Сретенка, 29
}

Статья посвящена 95-му дню рождения выдающегося ученого, замечательного, яркого человека, Галины Михайловны Андреевой (1924-2014). Воспоминания о научном руководителе возвращают автора в 90-е гг. прошлого века, когда студентам посчастливилось слушать курсы лекций Г.М. Андреевой по социальной психологии, истории зарубежной социальной психологии (именуемой «курсом на троих», поскольку читался совместно с Н.Н. Богомоловой и Л.А. Петровской) и психологии социального познания.

Перед читателями возникает образ основателя кафедры социальной психологии факультета психологии Московского государственного университета имени М.В. Ломоносова. Человека, судьба которого едва ли могла сложиться иначе: добровольный уход на фронт в 17 лет, обучение на философском факультете, пребывание у истоков второго рождения социологии в России, создание кафедры социальной психологии и школы отечественной социальной психологии, подготовка многих поколений социальных психологов...

Ключевые слова: Г.М. Андреева; социальная психология; история социальной психологии

13 июня 2019 г. Галине Михайловне Андреевой (ГМ - так называли Галину Михайловну на кафедре социальной психологии МГУ) исполнилось бы 95 лет (рис. 1).

Боль утраты немного притихла за прошедшие пять лет (Г.М. Андреева ушла из жизни 31 мая 2014 г.), хотя пустота не заполнилась. По словам Л. Лунгиной, эта пустота никогда не заполняется (Дорман, 2010).

Эти воспоминания о ГМ - некоторые штрихи к портрету необыкновенного человека, у которого мне повезло учиться, с которым посчастливилось проработать пятнадцать лет (рис. 2).

Л.Я. Гозман говорил о том, что написать связанный текст про ГМ сложно (2009). Я бы сказала, что очень сложно. Двадцать лет взаимодействия - это очень яркий период, воспоминания о котором я бережно храню.

(C) Бовина И.Б., 2019

This work is licensed under a Creative Commons Attribution 4.0 International License 


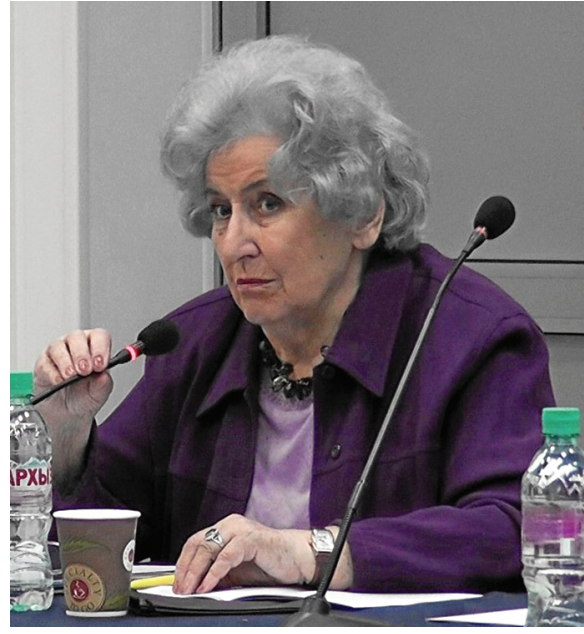

Рис. 1. Галина Михайловна Андреева на защите кандидатской диссертации Е.Б. Березиной, 25 ноября 2011 г., факультет психологии МГУ (фото Б.Б. Березина)

[Figure 1. Galina M. Andreeva at the defense of the Ph.D. thesis by E.B. Berezina, November 25, 2011, Faculty of Psychology, Moscow State University (photo by B.B. Berezin)]

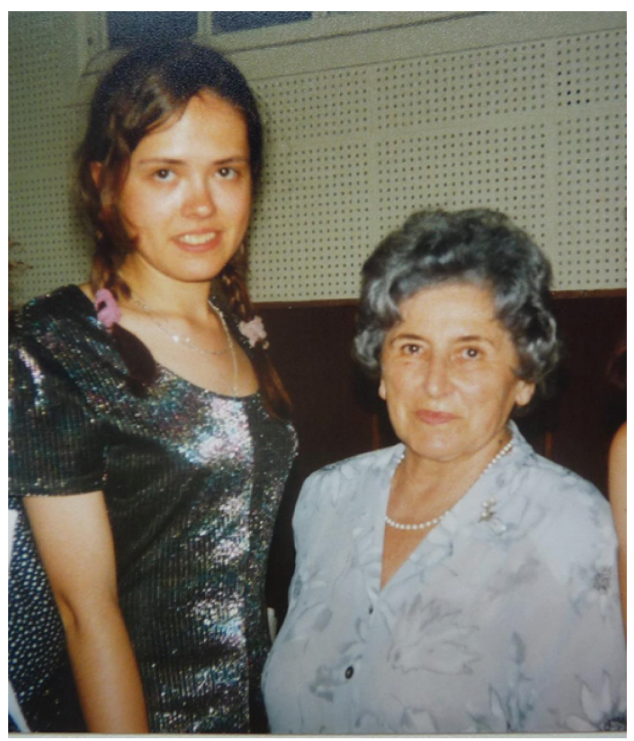

Рис. 2. И.Б. Бовина (слева) и Г.М. Андреева (75-летний юбилей Г.М. Андреевой, июнь 1999 г.) [Figure 2. Inna B. Bovina (left) and Galina M. Andreeva ( $75^{\text {th }}$ anniversary of G.M. Andreeva, June 1999)]

Думая о ГМ, вспомнился старинный эксперимент Э. Аронсона с коллегами (Aronson et al., 1966) по формированию впечатления, в котором проверялась гипотеза о том, повысится ли привлекательность высококомпетентного человека, если он совершит неуклюжую ошибку. Варьированию подвергались две переменные: 1) способности (высокие: правильные ответы на сложные вопросы викторины в $92 \%$ случаев в сочетании с коротким интервью, в котором персонаж сообщал, что он был отличником в университете, членом легкоатлетической команды, а также редактором ежегодника, и средние: правильные ответы в 30 \% 
случаев в сочетании с информацией о себе - был хорошистом в университете, корректором в ежегоднике, а попасть в легкоатлетическую команду не получилось); 2) неуклюжая ошибка - опрокинутая чашка кофе (наличие или отсутствие ошибки). Испытуемые в четырех группах среди прочего, отвечали на вопрос о привлекательности персонажа. Чем выше были способности, тем выше была межличностная привлекательность $(M=17,8$ против $M=20,8)$ при сравнении случаев, когда оцениваемые персонажи не совершали ошибок. Высокоспособный же персонаж в случае неуклюжей ошибки оценивался как более привлекательный, чем высокоспособный в ситуации отсутствия ошибки $(M=30,2$ против $M=20,8)$. Пафос эксперимента заключается в том, что неуклюжая ошибка приближала к нам этого высокоспособного субъекта, иначе - он «слишком хорош», так не бывает. Можно только сожалеть о том, что испытуемые Аронсона не оценивали реальность существования такого успешного персонажа. Он немного пугает, ведь столько знать - невозможно.

Вспомнился мне этот эксперимент, потому что ГМ как раз и была тем человеком, который столько знал и умел, сделал и был готов сделать в жизни, что становилось немного страшно... а бывает ли такое? Добровольно уйти на фронт в 17 лет, вернуться и закончить философский факультет, стоять у истоков второго рождения социологии в России, создать кафедру социальной психологии, написать серию учебников... (Памяти Галины Михайловны Андреевой..., 2015). Как бы не задевало за живое то, что И.С. Кон сказал в воспоминаниях о ГМ «Женщина на все времена», но это правда: «ГМ создала замечательную кафедру, воспитала прекрасных, высокопрофессиональных ученых, но ни один из них ей в подметки не годится» (Кон, 2009, с. 15).

Попасть к ГМ в качестве студентки мне удалось не сразу.

Первоначально моим научным руководителем был В.В. Агеев, но нашему взаимодействию, видимо, не суждено было сбыться по той причине, что Владимир Сергеевич - уже когда я училась на втором курсе - планировал отъезд в университет в Штаты, а курсовой третьего руководил дистанционно, оставив вместо себя аспирантку Надежду Захарову.

Итак, осенью 1993 г. нужно было определиться с новым научным руководителем. Никогда не забуду того напряжения, с которым я ожидала в коридоре ГМ после лекции. Историческое событие свершилось - у стенда расписания на третьем этаже психфака ГМ дала свое согласие на научное руководство. И началось замечательное время. Помню, как ГМ первый раз пригласила меня к себе домой, чтобы можно было серьезно обсудить программу исследования и план курсовой (на четвертом курсе была уже защита курсовых, не помню откуда пошло, но в кулуарах защита эта именовалась «избиением младенцев»; что-то это в те времена и значило). Объяснив, как добираться от «Киевской» до ее дома, ГМ в шутку сказала, мол, если заблудитесь, то в аспирантуру не возьму. Шутка шуткой, но образ желаемого будущего уже вырисовывался...

Сколько было этих встреч у ГМ, я никогда не считала, но в памяти осталось, что по мере обсуждения за окном, где шумят поезда, проносясь по старейшему в Москве метромосту, становилось темно, в комнате зажигался свет, а наша дис- 
куссия продолжалось. От актуальных вопросов исследования разговор переходил к обсуждению глобальных проблем социальной психологии, ГМ делилась воспоминаниями о выдающихся фигурах социальной психологии, с которыми была знакома лично. ГМ увлекла социальной психологией, влюбила в нее. Сколько всего интересного было в этих встречах, материализовывались самые различные события: советско-канадский конгресс по социальной психологии (1977 г.), конференции в рамках Европейской ассоциации по социальной психологии, поездка в лабораторию Г. Тэшфела, чтение лекций в Хельсинкском университете (Бовина, 2015).

Определившись с направлением, следуя семейным традициям, я выбрала социальную психологию, но понимание того, что это самое интересное пришло только благодаря ГМ.

Напрасны были мои опасения, что европейские коллеги знают больше, прочитали источники, которые нам просто негде было взять: не переведены на русский, а оригиналы отсутствуют в библиотеке (мое студенчество и аспирантство выпали на те времена, когда повседневного интернета еще не было, а доступ в электронную почту осуществлялся в кабинете С.Д. Смирнова два или три раза в неделю в определенное время). ГМ готовилась к лекциям по свежим иностранным изданиям, в своих лекциях транслировала нам социально-психологическое знание, преодолевая изоляцию, которой была подвергнута отечественная социальная психология. Таким образом, миноритарность отечественной социальной психологии не мешала нам быть зачастую достаточно осведомленными о западной социальной психологии (Conversations..., 2009).

Десять лет назад к 85-летию ГМ вышла книга под названием «Константа в неопределенном и меняющемся мире». ГМ действительно осталась константой в этом мире.

\section{Список литературы}

Бовина И.Б. Памяти научного руководителя // Вестник Российского университета дружбы народов. Серия: Психология и педагогика. 2015. № 1. С. 98-100.

Гозман Л.Я. ГМ // Константа в неопределенном и меняющемся мире: маленькая психологическая серенада к юбилею Г.М. Андреевой. 13.06.2009 / под ред. Ю.П. Зинченко, Т.Д. Марцинковской. М.: МГУ имени М.В. Ломоносова, 2009. С. 30-40.

Дорман О.В. Подстрочник: жизнь Лилианны Лунгиной, рассказанная ею в фильме Олега Дормана. М.: Corpus, 2010. 480 c.

Кон И.С. Женщина на все времена // Константа в неопределенном и меняющемся мире: маленькая психологическая серенада к юбилею Г.М. Андреевой. 13.06.2009 / под ред. Ю.П. Зинченко, Т.Д. Марцинковской. М.: МГУ имени М.В. Ломоносова, 2009. С. 15-18.

Памяти Галины Михайловны Андреевой (1924-2014) // Вестник Российского университета дружбы народов. Серия: Психология и педагогика. 2015. № 1. С. 96-97.

Aronson E., Willerman B., Floyd J. The effect of a pratfall on increasing interpersonal attractiveness // Psychological Science. 1966. Vol. 4. No. 6. Pp. 227-228.

Conversation with Willem Doise by Xenia Chryssochoou // European Bulletin on Social Psychology. 2009. Vol. 21. No. 1. Pp. 7-27. 


\title{
История статьи:
}

Поступила в редакцию: 25 апреля 2019

Принята к печати: 30 мая 2019

\section{Для цитирования:}

Бовина И.Б. Мой научный руководитель - ГМ: к 95-летию со дня рождения Г.М. Андреевой // Вестник Российского университета дружбы народов. Серия: Психология и педагогика. 2019. Т. 16. № 2. С. 287-292. http://dx.doi.org/10.22363/2313-1683-2019-16-2-287292

\section{Сведения об авторе:}

Бовина Инна Борисовна, доктор психологических наук, доцент, профессор кафедры клинической и судебной психологии, факультет юридической психологии, Московский государственный психолого-педагогический университет (Москва, Россия). Защитила под руководством Г.М. Андреевой диплом по специальности «Психология» (МГУ, 1995 г.), кандидатскую (МГУ, 1998 г.) и докторскую (МГУ, 2009 г.) диссертации по специальности «Социальная психология». E-mail: innabovina@yandex.ru

\section{Biographical article}

\section{My Scientific Supervisor - GM: to the $95^{\text {th }}$ Anniversary of G.M. Andreeva}

\author{
Inna B. Bovina
}

Moscow State University of Psychology and Education 29 Sretenka St., Moscow, 127051, Russian Federation

The article is devoted to the $95^{\text {th }}$ birthday of Galina M. Andreeva, an outstanding scientist, a wonderful, bright personality. Memories about the scientific supervisor brings back to the 90s of the last century, when students were lucky enough to listen to lectures of G.M. Andreeva on social psychology, history of western social psychology (shared with N.N. Bogomolova and L.A. Petrovskaya) and psychology of social cognition.

Readers can easily imagine the founder of the Social Psychology Department at the Faculty of Psychology of the Lomonosov Moscow State University. A person with an outstanding life, that could hardly have been imagined otherwise: a voluntary participation in the WW2, studies at the Faculty of Philosophy, the rebirth of sociology in Russia, the foundation of the Department of Social Psychology, and many generations of social psychologists...

Key words: Galina M. Andreeva; social psychology; history of social psychology

\section{References}

Aronson, E., Willerman, B., \& Floyd, J. (1966). The effect of a pratfall on increasing interpersonal attractiveness. Psychological Science, 4(6), 227-228.

Bovina, I.B. (2015). In Memoriam of Scientific Supervisor. RUDN Journal of Psychology and Pedagogics, (1), 98-100. (In Russ.) 
Conversation with Willem Doise by Xenia Chryssochoou (2009). European Bulletin on Social Psychology, 21(1), 7-27.

Dorman, O. (2010). Podstrochnik: The Life of Lilianna Lungina, as she narrated in the Oleg Dorman film. Moscow: Corpus Publ. (In Russ.)

Gozman, L.Ya. (2009). GM. In Yu.P.Zinchenko, \& T.D.Martsinkovskaya (Eds.), Constant in an Uncertain and Changing World: A Small Psychological Serenade for the Anniversary of G.M. Andreeva. 13 June 2009 (pp. 30-40). Moscow: Lomonosov MSU Publ. (In Russ.)

In Memory of Galina M. Andreeva (1924-2014). (2015). RUDN Journal of Psychology and Pedagogics, (1), 96-97. (In Russ.)

Kon, I.S. (2009). Woman for all time. In Yu.P.Zinchenko, \& T.D.Martsinkovskaya (Eds.), Constant in an Uncertain and Changing World: A Small Psychological Serenade for the Anniversary of G. M. Andreeva. 13 June 2009 (pp. 15-18). Moscow: Lomonosov MSU Publ.

\section{Article history:}

Received: 25 April 2019

Revised: 27 May 2019

Accepted: 30 May 2019

\section{For citation:}

Bovina, I.B. (2019). My Scientific Supervisor - GM: to the 95th Anniversary of G.M. Andreeva. RUDN Journal of Psychology and Pedagogics, 16(2), 287-292. http://dx.doi.org/10.22363/23131683-2019-16-2-287-292

\section{Bio Note:}

Inna B. Bovina, D.Sc. in Social Psychology, is Professor at the Department of Clinical and Legal Psychology, Moscow State University of Psychology and Education (Moscow, Russia). E-mail: innabovina@yandex.ru 